\title{
Pengaruh Waktu Pelapisan Spermatozoa Sapi Pada Media TALP yang Disuplementasi bovine serum albumin (BSA) Terhadap Jenis Kelamin Embrio In vitro
}

\section{The Influence of Time Veneering Cow of Spermatozoa in Media of TALP which Supplementazion by Bovine Serum of Albumin (BSA) to Gender Embryo of In vitro}

\author{
T. Afriani, Z. Udin, Jaswandi, dan S. Asmairicen \\ Fakultas Peternakan Universitas Andalas \\ Kampus Unand Limau Manis Padang, 25153 \\ e-mail: op3martshar@yahoo.co.id
}

(Diterima: 8 Maret 2011; Disetujui: 23 Mei 2011)

\begin{abstract}
This research aim to know the influence of depth veneering time of spermatozoa at media of TALP which was supplemented by $4 \%$ BSA to embryo gender in in-vitro and to get the time dissociation of spermatozoa which have the best chromosome $Y$. This research represent attempt of exsperiment in RBT by 4 time veneering of spermatozoa as treatment, times intake of semen of epididymis to groups. Variables measure are: 1). mortality of spermatozoa, 2). number of in vitro fertilzation, 3. masculine gender embryo ratio. Result shown, the veneering of cow spermatozoa during 90 minute in media of TALP which was supplemented by $4 \%$ bovine serum albumin (BSA) can dissociate spermatozoa which have chromosome $Y$ with percentage of highest male sex $(90.00 \pm 24.49)$, and highest percentage of mortality and fertility were obtained at veneering during 60 minute with scoring $73.33 \pm 5.16$ and $53.92 \pm 18.79$ respectively
\end{abstract}

Keywords:bovine serum albumin (BSA), veneering, spermatozoa, embryo

\section{PENDAHULUAN}

Upaya peningkatan produktivitas sapi tidak dapat dipisahkan dari upaya pengaturan dinamika populasi seperti tingkat kelahiran, pemotongan ternak dan penekanan angka kematian. Hal ini mempunyai kaitan yang kuat dengan sistem pengelolaan usaha peternakan.Untuk itu usaha peternakan rakyat baik yang bersifat intensif maupun ekstensif perlu dikembangkan dengan bioteknologi reproduksi.

Secara umum bioteknologi reproduksi merupakan teknologi unggulan dalam memproduksi dan meningkatkan produktivitas peternakan. Terkandung di dalamnya pemanfaatan proses rekayasa fungsi reproduksi dan genetika dalam upaya meningkatkan mutu dan jumlah produksi serta akan menjadi titik tolak bagi pengembangan industri ternak masa datang. Hal ini sangat mendukung program breeding dalam pemilihan bibit unggul dan menunjang efisiensi pada peternakan sapi potong.

Salah satu upaya untuk menghasilkan anak sesuai harapan dapat dilakukan dengan cara seksing spermatozoa berkromosom $\mathrm{X}$ atau $\mathrm{Y}$ sebelum dilakukan program Inseminasi Buatan. Inseminasi dengan semen pembawa kromosom $\mathrm{X}$ akan didapatkan pedet betina penerus keturunan dengan kualitas yang baik. Sedangkan inseminasi dengan spermatozoa pembawa kromosom $\mathrm{Y}$ akan didapatkan pedet jantan yang lebih menguntungkan. Sapi jantan tumbuh lebih cepat dan porsi karkasnya lebih tinggi dari pada porsi karkas sapi betina, sehingga meningkatnya jumlah anak jantan, berarti memperbaiki penampilan pertumbuhan dan peningkatan berat potong. Berdasarkan perbedaan tujuan usaha tersebut, maka pengaturan jenis kelamin dapat menekan perolehan ternak dari jenis kelamin yang kurang dibutuhkan. Dengan demikian apabila semen sapi yang sudah dipisahkan berdasarkan jenis kelaminnya dipakai untuk 
Inseminasi Buatan, maka efisiensi produksi akan dapat ditingkatkan.

Rasio alamiah spermatozoa pembawa kromosom X dan Y umumnya adalah $50 \% \mathrm{X}$ dan 50\% Y. Berbagai upaya telah dilakukan untuk mengubah rasio tersebut pada ternak dengan maksud untuk dapat mengendalikan jenis kelamin anak dari suatu kelahiran. Manipulasi semen ternak melalui seksing merupakan salah satu cara utama untuk memperoleh anak dengan jenis kelamin tertentu. Sperma seksing digunakan untuk Inseminasi Buatan dapat menghasilkan perolehan ternak dari jenis kelamin yang dikehendaki dengan genetik tertentu. Disamping itu peningkatan genetik dalam kelompok ternak dapat menjadi lebih cepat.

Keberhasilan penggunaan bovine serum albumin (BSA) dan ovalbumin sebagai media pemisahan spermatozoa diawali oleh Ericsson et al. (1973). Selanjutnya ditambahkan oleh Udin et al (2006), salah satu usaha yang dilakukan pada teknik FIV (Fertilisasi In Vitro) adalah mencoba memodifikasi medium yang digunakan untuk meningkatkan viabilitas spermatozoa sehingga mampu membuahi oosit. Penggunaan bovine serum albumin ini sudah banyak dilakukan oleh peneliti sebelum nya diantaranya Max-Well et al (1984) yang menggunakan untuk pemisahan spermatozoa $X$ dan Y pada sapi, Jaswandi (1992) memisahkan spermatozoa $\mathrm{X}$ dan $\mathrm{Y}$ sapi perah dan Hendri (1992) melakukan pemisahan spermatozoa $\mathrm{X}$ dan $\mathrm{Y}$ pada kambing. Namun pada penelitian sebelumnya lebih mengarahkan pada pengaruh pengencer dalam proses pemisahan kromosom $\mathrm{X}$ dan $\mathrm{Y}$, sedangkan yang menjadikan waktu sebagai perlakuan belum pernah dilakukan. Pada penelitian ini dilakukan pelapisan spermatozoa dengan menggunakan media TALP dan bovine serum albumin 4\% dengan membiarkan sperma berenang ke bawah (swim down) pada fertilisasi in vitro, dengan mengamati lamanya waktu yang tepat dalam hal pemisahan spermatozoa kromosom X dan Y. Dimana diharapkan media TALP dan BSA tersebut berfungsi untuk seleksi jenis kelamin serta berperan pada proses pemisahan antar plasma semen dengan spermatozoa.

Bertolak dari uraian di atas, sudah dilakukan penelitian untuk mengetahui waktu yang efektif pada pelapisan spermatozoa dengan media TALP yang disuplementasi $4 \%$ bovine serum albumin terhadap perbandingan jenis kelamin embrio in vitro. Dimana pada penelitian tersebut spermatozoa diambil dari epidydimis dan dimasukkan ke corong pemisah yang terlebih dahulu diisi media lalu dilapisi dengan spermatozoa di atasnya.

\section{MATERI DAN METODE PENELITIAN}

Tempat pelaksanaan penelitian di Laboratorium Fisiologi Reproduksi Ternak Fakultas Peternakan dan Laboratorium Pemuliaan Tanaman Budidaya Pertanian Fakultas Pertanian Universitas Andalas.

\section{Materi Penelitian}

Bahan yang digunakan adalah semen sapi yang diambil dari epididimis dan ovarium yang berasal dari (RPH) Rumah Potong Hewan, bovine serum albumin (BSA), $\mathrm{NaCl}$ fisiologis, Aquades, TALP, Serum sapi, Gentamisin, Insulin, TCM-199, PBS (phosphate buffer saline), FSH, Hepes, RTG, Agar powder, $\mathrm{dd}_{2} \mathrm{O}$, bromide penol blue (BPB), TBE Buffer, ethidium bromide, primer (BOVSP-f, BOVSP-R, BOV97M-F, BOV97M-R), Marker (1KB). Peralatan yang digunakan adalah tongkat pelican / pengaduk gelas kaca, corong pemisah $25 \mathrm{ml}$, Objek dan cover glass, Mikroskop binocular, Hemocytometer, kertas tissue, alumunium foil, parafilm , gelas erlemayer $(100 \mathrm{ml})$, gelas ukur $250 \mathrm{ml}$ dan $10 \mathrm{ml}$, timbangan elektrik, sendok kecil,silet ,corong pemisah $250 \mathrm{ml}$, sentrifuge dan tabungnya, pinset, mesin PCR, mesin elekroforesis, comb 8 slot (pembuat lobang untuk DNA yang dicetak pada agar), perangkat pemotretan hasil PCR.

Prosedur penelitian

- Ovum diambil dari RPH lalu oocit dikoleksi dengan cara di slycing media yang akan digunakan PBS (phosphate 
buffer saline), selanjutnya diletakkan pada drop-drop dalam petridis yang masing-masingnya berisi 20 oocyt yang jadi jumlah oocyt secara keseluruhan adalah 80 oocyt. Oocyt yang didapat dari yang dikoleksi dimatangkan atau dimaturasikan selama 18-24 jam pada inkubator $\mathrm{CO}_{2} 5 \%$. Oocyt matang yang didapat berkisar dari 30\% - 70\%,

- Selanjutnya oocyt difertilisasikan dengan spermatozoa yang terlebih dahulu diberi perlakuan,media yang digunakan media TALP. Dimana perlakuan yang diberikan adalah semen dimasukkan kedalam corong pemisah sebanyak $100 \mu \mathrm{l}$ yang terlebih dahulu di isi dengan $3 \mathrm{ml}$ media TALP yang disuplementasi $4 \%$ BSA yang mana lapisan bawah merupakan media dan lapisan atas adalah semen. Hal tersebut bertujuan untuk pemisahan kromosom spermatozoa $X$ dan Y. Selanjutnya spermatozoa dibiarkan berenang kebawah (swim-down) dengan waktu 30, 60, 90 dan 120 menit pada suhu kamar. Setelah waktu yang ditentukan diambil terlebih dahulu yang berenang kebawah diperkirakan adalah spermatozoa Y, yang kemudian difertilisiasikan dengan oocyt yang telah matang Media akan diganti dengan Selanjutnya dikultur dalam inkubator $\mathrm{CO} 2 \quad 5 \%$ sampai terbentuk 2 sel, 4 sel, 8 sel, 16 sel dan morula yang selanjutnya akan diuji dengan uji PCR, sebagai metode untuk analisa sexing spermatozoa $\mathrm{X}$ dan $\mathrm{Y}$.

Hasil dari metode PCR yang telah di foto elekroforesis terlihat pada gambar 1 .

\section{Metode Penelitian}

Rancangan percobaan yang digunakan adalah Rancangan Acak Kelompok (RAK) dengan 4 macam perlakuan dan 6 ulangan, dimana ulangan dijadikan sebagai kelompok. Lamanya waktu yang diperhatikan untuk spermatozoa berenang meliputi 30 menit, 60 menit, 90 menit dan 120 menit yang merupakan perlakuan. Dan hari pengambilan semen dari epididymis adalah sebagai kelompok.

\section{HASIL DAN PEMBAHASAN}

\section{Kualitas Semen Cair}

Karakteristik spermatozoa yang berasal dari epididymis yang dievaluasi secara makroskopis untuk menggambarkan kualitas semen cair sebelum diberi perlakuan adalah berwarna krem, berbau khas spermatozoa, $\mathrm{pH} 7$, volume $0,3-0,5 \mathrm{ml}$ dan konsistensi sangat kental.

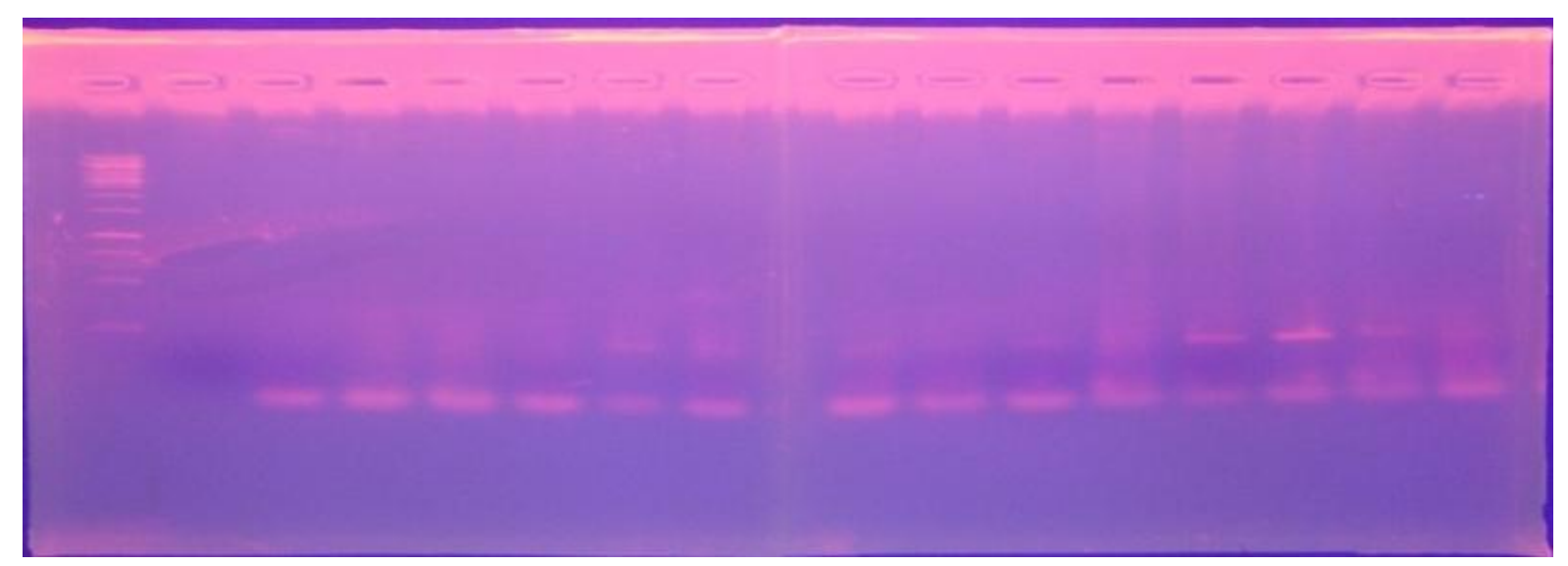

Gambar 1. Foto elektroforesis embrio hasil PCR, terlihat 2 ban yang menandakan jantan,(Y) dan yang 1 ban betina $(\mathrm{X})$. dimana perbandingan jantan 12 : betina 2 (Sumber : foto hasil penelitian 2010). 
Tabel 1. Persentase rataan motilitas pada berbagai waktu pelapisan spermatozoa

\begin{tabular}{ccccc}
\hline \multirow{2}{*}{ Kelompok } & \multicolumn{4}{c}{ Waktu Pelapisan } \\
\cline { 2 - 5 } & 30 & 60 & 90 & 120 \\
\hline 1 & 80 & 80 & 70 & 60 \\
2 & 80 & 70 & 60 & 50 \\
3 & 70 & 70 & 60 & 60 \\
4 & 80 & 80 & 70 & 60 \\
5 & 70 & 70 & 60 & 50 \\
6 & 80 & 70 & 60 & 60 \\
\hline Jumlah & 460 & 440 & 380 & 340 \\
\hline Rataan & $76.67^{\mathrm{a}} \pm 5.16$ & $73.33^{\mathrm{a}} \pm 5.16$ & $63.33^{\mathrm{b}} \pm 5.16$ & $56.67^{\mathrm{c}} \pm 5.16$ \\
\hline
\end{tabular}

Keterangan : Superskrip yang berbeda dengan huruf yang berbeda pada baris menunjukkan rataan perlakuan berbeda nyata $(\mathrm{P}<0,05)$.

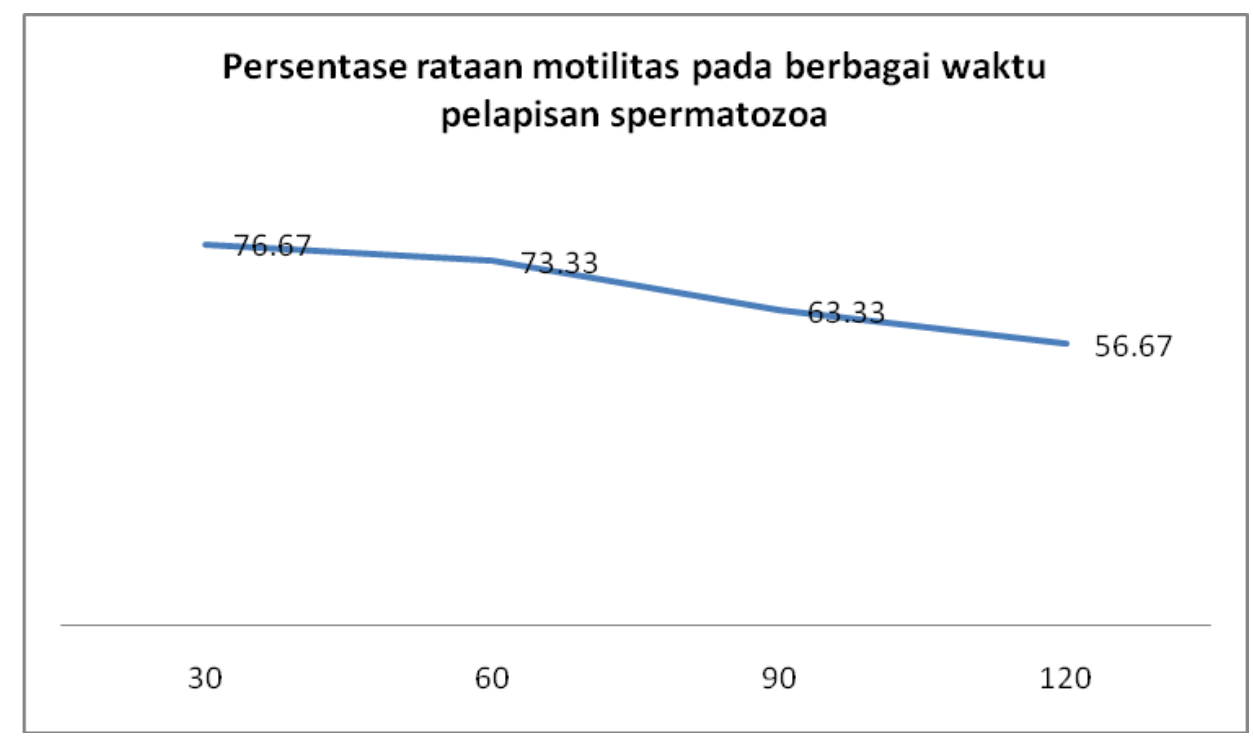

Gambar 2. Grafik persentase rataan motilitas pada berbagai waktu pelapisan spermatozoa

\section{Motilitas spermatozoa dengan berbagai waktu pelapisan spermatozoa}

Dari hasil penelitian yang menunjukan terjadi penurunan persentase motilitas pada setiap waktu pelapisan spermatozoa. Penurunan ini disebabkan oleh semakin lamanya waktu yang dipakai dan pegantian plasma semen dengan media TALP yang disuplementasi dengan $4 \%$ bovine serum albumin (BSA). Hal tersebut dapat dilihat pada tabel yang ditampilkan berikut ini.

Hasil analisa statistik pengaruh waktu pelapisan spermatozoa terhadap motilitas spermatozoa sangat berbeda nyata $(P<0,01)$ namun hasil uji DMRT menunjukan bahwa perlakuan waktu pelapisan spermatozoa yang disuplementasi dengan $4 \%$ bovine serum albumin (BSA) berbeda nyata $(\mathrm{P}<0,05)$ terhadap motilitas sperma. Dengan demikian waktu pelapisan spermatozoa berpengaruh nyata terhadap motilitas spermatozoa. Namun demikian dengan angka rata-rata terendah motilitas sebanyak 56,67\% masih dianggap memiliki motilitas yang baik. Sesuai dengan pendapat Toelihere ( 1993) spermatozoa motil untuk semen ejakulat sapi berkisar $50-80 \%$. Hal ini berarti bahwa waktu pelapisan spermatozoa yang disuplementasi $4 \%$ bovine serum (BSA) 
akan menyebabkan motilitas semakin rendah bersamaan dengan semakin lamanya waktu. Sesuai dengan penelitian yang dilakukan oleh Nurani ( 2005) yang mendapatkan angka penurunan motilitas spermatozoa secara ratarata sebanyak $6,75 \%$. Susilawati et al (2002) menyatakan bahwa penurunan laju motilitas spermatozoa berkurang akibat proses metabolisme yang terus berjalan. Perbedaan antara perlakuan disebabkan karena adanya berbagai perubahan yang terjadi bersamaan diikuti oleh reaksi akrosom secara fisiologis dengan semakin banyak energy yang digunakan spermatozoa untuk selalu bergerak (Bedford 1983; Trounson,1992).

\section{Tingkat fertilisasi spermatozoa dengan berbagai waktu pelapisan spermatozoa}

Rataan persentase angka fertilisasi pada masing-masing perlakuan 30 menit, 60 menit,90 menit dan 120 menit, yang dilakukan secara in vitro dapat dilhat pada Tabel 5.

Tabel 2. Persentase angka fertilisasi pada berbagai waktu pelapisan spermatozoa dalam media TALP yang disuplementasi $4 \%$ bovine serum albumin (BSA)

\begin{tabular}{cllll}
\hline \multirow{2}{*}{ Kelompok } & \multicolumn{4}{c}{ Waktu Pelapisan (menit) } \\
\cline { 2 - 5 } & 30 & 60 & 90 & 120 \\
\hline 1 & $20.00^{(2 / 10)}$ & $60.00^{(3 / 5)}$ & $71.42^{(5 / 7)}$ & $37.50^{(3 / 8)}$ \\
\hline 2 & $37.50^{(3 / 8)}$ & $66.67^{(4 / 6)}$ & $44.44^{(4 / 9)}$ & $51.14^{(4 / 7)}$ \\
\hline 3 & $44.44^{(4 / 9)}$ & $60.00^{(6 / 10)}$ & $50.00^{(3 / 6)}$ & $50.00^{(4 / 8)}$ \\
\hline 4 & $60.00^{(3 / 5)}$ & $71.42^{(5 / 7)}$ & $50.00^{(4 / 8)}$ & $50.00^{(5 / 10)}$ \\
\hline 5 & $62.50^{(5 / 8)}$ & $20.00^{(2 / 10)}$ & $41.67^{(2 / 12)}$ & $46.67^{(5 / 12)}$ \\
\hline 6 & $75.00^{(6 / 8)}$ & $45.45^{(5 / 11)}$ & $54.00^{(3 / 12)}$ & $54.00^{(6 / 11)}$ \\
\hline Jumlah & 294.44 & 323.54 & 311.53 & 295.31 \\
\hline Rataan & $49.91^{\mathrm{a}} \pm 19.84$ & $53.92^{\mathrm{b}} \pm 18.79$ & $51.92^{\mathrm{c}} \pm 120.52$ & $49.21^{\mathrm{d}} \pm 5.85$ \\
\hline
\end{tabular}

Keterangan: Superskrip yang berbeda dengan huruf yang berbeda pada baris menunjukkan rataan perlakuan berbeda nyata $(\mathrm{P}<0,05)$

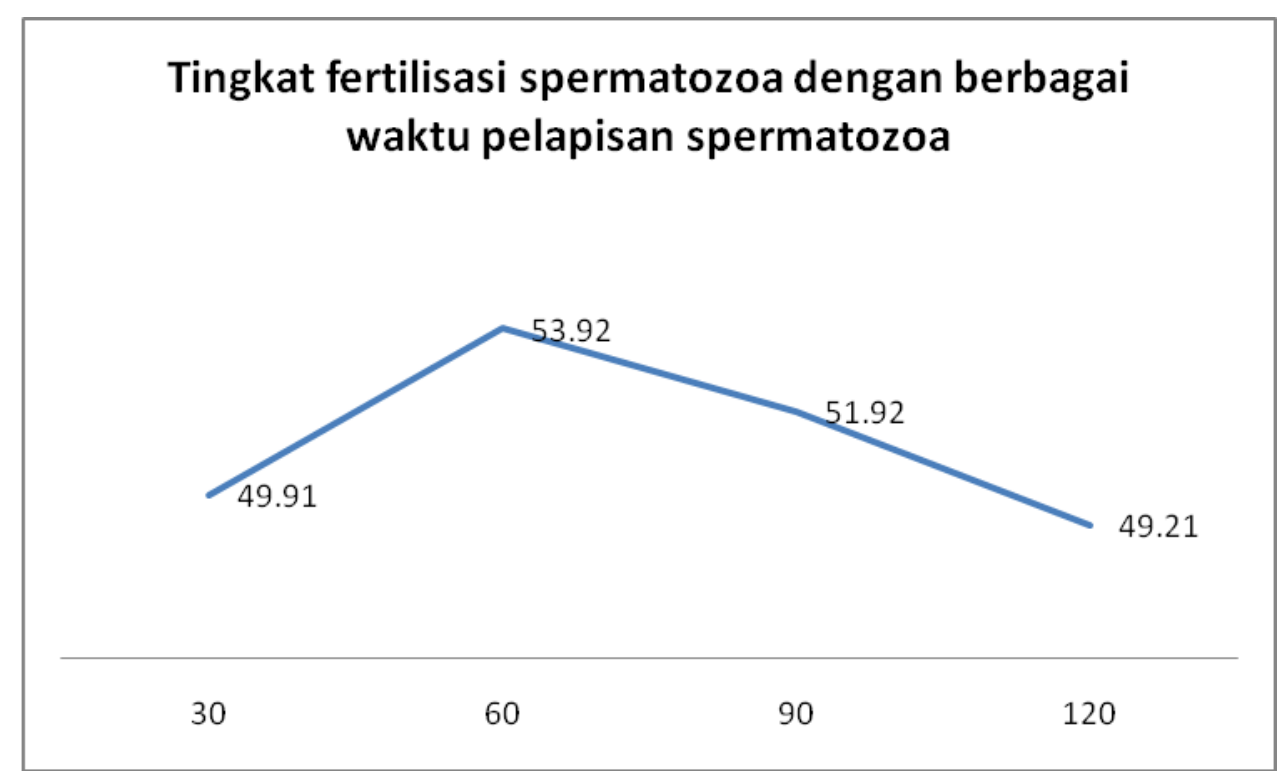

Gambar 3. Grafik tingkat fertilisasi spermatozoa dengan berbagai waktu pelapisan spermatozoa 
Tingkat fertilisasi yang tertinggi terlihat pada perlakuan 60 menit adalah 53.92 $\%$ dan yang terendah pada perlakuan 120 menit yaitu $49.21 \%$. Pada pengambilan data angka fertilitilisasi adalah oocyt yang dikoleksi 20 oocyt untuk satu petridis, dan tidak semuanya yang matang. Dan oocyt yang terfertilisasi tidak semua yang telah matang, serta angka-angka fertilisasi dapat dilihat dari tabel dan grafik

Hasil analisis statistik menunjukan
bahwa pengaruh spermatozoa terhadap tingkat fertilisasi tidak berbeda nyata $(\mathrm{P}>0,05)$. Hal ini memperlihatkan bahwa waktu pelapisan spermatozoa tidak mempengaruhi kemampuan sel spermatozoa untuk membuahi sel telur, pada penelitian ini sel spermatozoa terdapat pada media TALP yang disuplementasi $4 \%$ BSA, dimana media TALP yang disuplementasi 4\% BSA berfungsi sebagai pengganti plasma semen atau sebagai sumber makanan sehingga dapat mempertahankan daya hidup spermatozoa. Hasil ini sesuai dengan pernyataan Sujoko (2009) pendapat (Morrel, 2006) bahwa keberhasilan Fertilisasi in vitro salah satunya dipengaruhi oleh kualitas spermatozoa. Dan (Herdis et al .,2005) Kualitas spermatozoa yang dimaksud adalah spermatozoa yang mempunyai daya hidup tinggi,morfologi normal dan motilitas progresif. Boediono et al (2000) untuk menjaga kehidupannya saat dipakai dalam proses fertilisasi in vitro, spermatozoa biasanya diinkubasi dalam media tertentu sehingga daya hidup, daya tahan dan kapasitasinya terjaga sebelum di inkubasi bersama sel telur secara alami, spermatozoa yang dibiarkan dalam media tertentu akan mengalami proses aglutinasi atau penggumpalan. Secara tidak langsung proses aglutinasi akan menurunkan tingkat efisiensi sperma dalam membuahi sel telur (Thundhatil,1998).

\section{Rasio Jenis Kelamin}

Rataan rasio jenis kelamin jantan pada pada masing-masing perlakuan 30 menit, 60 menit, 90 menit dan 120 menit dapat dilihat pada Tabel 6. Dimana angka persentase jantan tertinggi terdapat pada perlakuan yaitu pada perlakuan waktu 90 menit yaitu $90,00 \%$ dan persentase yang paling terendah pada perlakuan yang ke 4 pada waktu 120 menit yaitu 73,89 \%. Secara keseluruhan persentase rataan yang terbesar didapat pada persentase jantan, hal ini disebabkan oleh perbedaan kecepatan spermatozoa Y dan Y dalam menembus larutan media TALP yang disuplementasi 4\% BSA. Sesuai dengan pendapat Goodall \& Robert (1976) yang menyatakan spermatozoa Y dengan bentuk yang lebih kecil serta mengandung DNA lebih sedikit mempunyai daya gerak yang lebih tinggi dibanding spermatozoa $\mathrm{X}$.

Tabel 3. Persentase jenis kelamin jantan pada berbagai waktu pelapisan spermatozoa dalam media TALP yang disuplementasi $4 \%$ bovine serum albumin (BSA)

\begin{tabular}{crrrr}
\hline \multirow{2}{*}{ Kelompok } & \multicolumn{4}{c}{ Waktu pelapisan (menit) } \\
\cline { 2 - 5 } & \multicolumn{1}{c}{60} & 60 & \multicolumn{1}{c}{90} \\
\hline 1 & $100.00^{(2 / 2)}$ & $66.67^{(2 / 3)}$ & $40.00^{(2 / 5)}$ & $0.00^{(0 / 3)}$ \\
2 & $66.67^{(2 / 3)}$ & $25.00^{(1 / 4)}$ & $100.00^{(4 / 4)}$ & $100.00^{(4 / 4)}$ \\
3 & $100.00^{(4 / 4)}$ & $83.33^{(5 / 6)}$ & $100.00^{(3 / 3)}$ & $100.00^{(4 / 4)}$ \\
4 & $100.00^{(3 / 3)}$ & $100.00^{(2 / 2)}$ & $100.00^{(3 / 3)}$ & $100.00^{(4 / 4)}$ \\
5 & $60.00^{(3 / 5)}$ & $100.00^{(2 / 2)}$ & $100.00^{(2 / 2)}$ & $60.00^{(3 / 5)}$ \\
6 & $85.71^{(5 / 6)}$ & $80.00^{(4 / 5)}$ & $100.00^{(3 / 3)}$ & $83.33^{(5 / 6)}$ \\
\hline Jumlah & 512.38 & 455.00 & 540.00 & 443.33 \\
\hline Rataan & $85.39^{\mathrm{a}} \pm 18.09$ & $75.83^{\mathrm{a}} \pm 27.96$ & $90.00^{\mathrm{a}} \pm 24.49$ & $73.89^{\mathrm{a}} \pm 39.46$ \\
\hline
\end{tabular}

Keterangan : Superskrip yang berbeda dengan huruf yang berbeda pada baris menunjukkan rataan perlakuan berbeda nyata $(\mathrm{P}<0,05)$. 


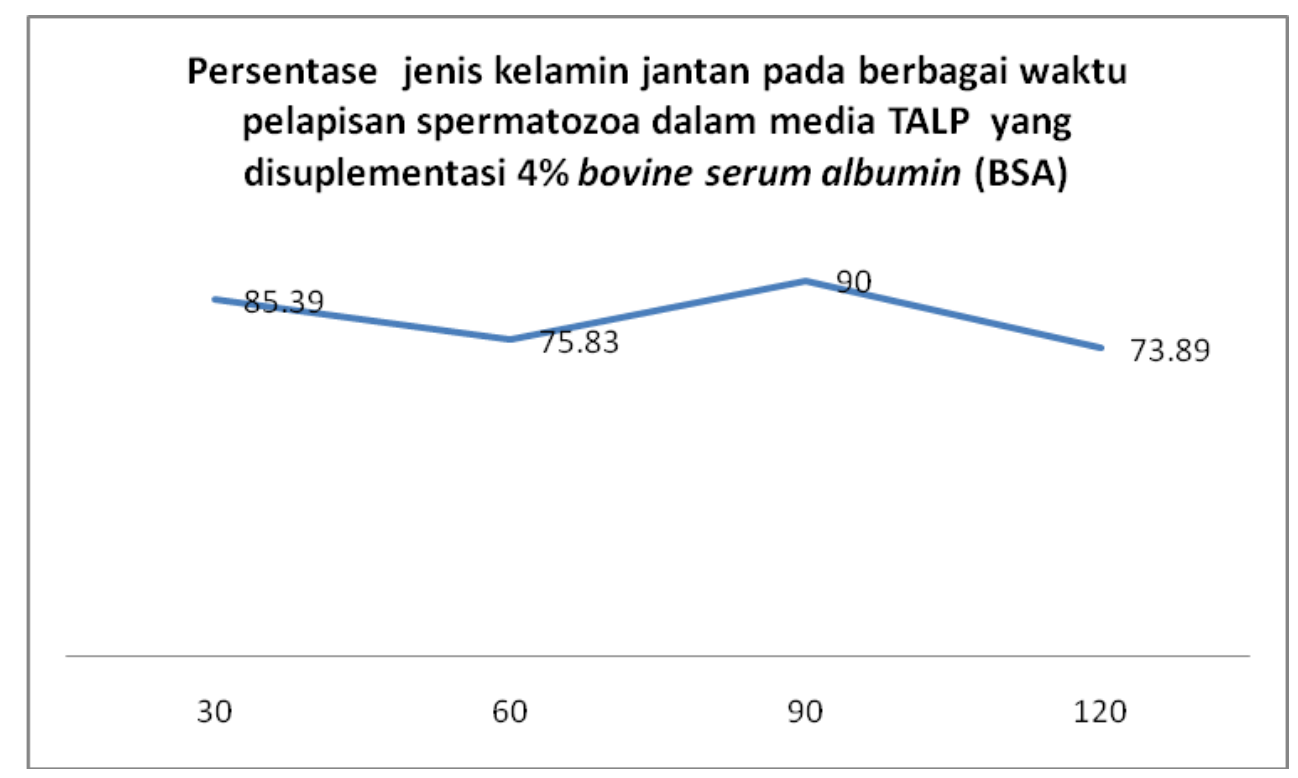

Gambar 4. Grafik persentase jenis kelamin

Hasil analisis statistik menunjukan bahwa pengaruh waktu pelapisan sperma terhadap penentuan rasio jenis kelamin tidak berbeda nyata $(\mathrm{P}>0,05)$. Hal ini memperlihatkan bahwa waktu tidak memberi pengaruh terhadap rasio jenis kelamin.

Persentase rasio jenis kelamin jantan lebih banyak dibandingkan dari yang betina. Sesuai dengan penelitian yang dilakukan Jaswandi (1992) yang melakukan pemisahan sperma pada sapi perah menggunakan larutan BSA $6 \%$ dan $10 \%$ dan mengungkapkan dengan fraksi semen bagian bawah didapatkan rasio jenis kelamin jantan dan betina ( $62,5 \%: 37,5 \%)$.

Tujuan dari penelitian ini adalah memisahkan spermatozoa kromosom $\mathrm{X}$ dan Y. Berdasarkan data yang didapat terlihat bahwa spermatozoa kromosom Y lebih banyak jumlahnya dari pada spermatozoa dengan kromosom $\mathrm{X}$. Hal ini sesuai dengan pendapat Max-well et al. (1984) dalam Afiati (2004) berpendapat efisiensi usaha mengubah rasio spermatozoa $\mathrm{X}$ dan $\mathrm{Y}$ dipengaruhi oleh beberapa factor, antara lain konsentrasi BSA, waktu atau lamanya spermatozoa menembus larutan BSA,dan konsentrasi spermatozoa yang akan dipisahkan dalam cairan pengencer. Selanjutnya Hendri (1992) menambahkan pemisahan spermatozoa pembawa kromosom
$\mathrm{X}$ dan $\mathrm{Y}$ ternak kambing dengan metode kolum menggunakan bovine serum albumin (BSA) 6\%, imbangan jenis kelamin jantan dan betina setelah perlakuan adalah $65 \%$ : $35 \%$.

\section{KESIMPULAN}

Berdasarkan hasil penelitian dapat disimpulkan bahwa pelapisan spermatozoa sapi persentase motilitas dan fertilisasi tertinggi diperoleh pada pelapisan selama 60 menit yaitu $73.33 \pm 5.16$ dan $53.92 \pm 18.79$, berbeda nyata $(\mathrm{P}<0,05)$. Sedangkan untuk persentase jenis kelamin tidak berbeda nyata (P> 0,05), hal ini disebabkan pengambilan waktu yang terlalu panjang. Jadi disarankan adanyan penelitian yang lebih lanjut mengenai waktu ini.

\section{DAFTAR PUSTAKA}

Fiati, F. 2004. Proporsi dan Karakteristik Spermatozoa X dan Y Hasil Separasi Kolum Albumin. Pusat Penelitian Bioteknologi - LIPI. Media Peternakan, 27(1), $16-20$.

Ericson, R.J. Langevind, C.N. and Nishino,M.1973, Isolation of fractions rich in human Y Sperm. Nature, 246, $421-424$. 
Frandson, R.D.1992. Anatomi dan Fisiologi Ternak.Edisi ke-4. Universitas Gajah Mada. Jogjakarta.

Goodall, H. and A.M Robert. 1976. Differences in motility of human $\mathrm{X}$ and Y- bearing Spermatozoa.J. Reprod. Fert., 48, 437.

Hendri. 1992. Upaya Pemisahan Sperma X dan $Y$ menggunakan BSA 6\% dengan menggunakan metode kolom terhadap angka kelahiran, angka kebuntingan dan sex ratio anak pada kambing. Prog. Pasca Sarjana. IPB. Tesis. Program Biologi Reproduksi.

Jaswandi.1992. Penggunaan Lapisan Suspensi bovine serum albumin (BSA) $6 \%$ dan $10 \%$ dalam kolom untuk memisahkan sperma sapi pembawa kromosom $\mathrm{X}$ dan $\mathrm{Y}$ guna mengubah rasio seks pada pedet. Tesis. Prog Pasca Sarjana Institute Pertanian Bogor, IPB.

Maxwell, W.M.C.G.Mendoza ans I.G. White. 1984. Post-Thawing survival of motile ram sperm after isolation by layering on protein colums. Therionology, 21. (4).

Nurani. 2005. Pengaruh Penambahan Heparin Pada Level Berbeda Terhadap
Kualitas Semen Cair Kambing Boer Hasil Pemisahan Spermatozoa $X$ dan Y. Fakultas Peternakan Universitas Hasanuddin,Makasar.

Sujoko, H., Setiadi. M.A. Boediono.A,2009. Seleksi Spermatozoa Domba Garut dengan Metode Sentrifugasi Gradient Densitas Percoll. Jurnal Veteriner, 10, $125-132$.

Susilawati, T, Hermanto,P. Srianto da e. Yuliani. 2002. Pemisahan Spermatozoa $X$ dan $Y$ pada Sapi Brahman Menggunakan Gradient Putih Telur pada Pengencer Tris Dan Tris Kuning Telur. Jurnal Ilmu-ilmu Hayati, 14(2), $176-181$.

Toelihere,M.R.1993. Fisiologi Reproduksi Pada Ternak.Angkasa Bandung.

Trounson, A, D. Pushett, L.J Maclellan, I. Lewis and Gardner. 1994. Currentn status of IVM/IVF and embryos cultura in human and farm animals. Theriogenolgy, 39, 1153-1171

Udin, Z., Jaswandi dan M. Hiliati. (2006) Pengaruh Penggunaan Hemikalsium Dalam Medium Fertilisasi in vitro Terhadap Viabilitas dan Aglutinasi Spermatozoa Sapi. Fakultas Peternakan Universitas Andalas. Padang. 